\title{
Education Financing in Kenya: Parents' Perceptions about the Implementation of the Cost-Sharing Policy in Secondary School Education
}

\author{
Jedidah Wambugu \\ Sello Mokoena \\ jeddywam@yahoo.co.uk,mokoesp@unisa.ac.za
}

Doi:10.5901/mjss.2013.v4n13p441

\begin{abstract}
The purpose of this article is twofold. First, to determine the direct costs incurred by parents as part of the cost-sharing policy to finance secondary school education in Kenya and, second, to assess the views of parents about the impact of the costsharing policy. A case study design involving qualitative data was used. Interviews were conducted with parents who serve on the school district committee. Findings revealed that that there has been an increase in school fees at secondary school level as a result of the introduction of the cost-sharing policy in Kenya. Children from poor backgrounds continue to be marginalised as some national schools charge exorbitant school fees. Consequently, most parents view cost sharing as a burden, because not all of them are able to educate their children beyond the primary school level. In addition, some children are not able to register at the schools of their choice and, to reduce expenditure related to school fees, they end up at district secondary schools. Based on the findings the study offers some recommendations for the policy-makers to consider.
\end{abstract}

Keywords: Cost-sharing; secondary school education; perceptions; parents; impact; Kenya

\section{Introduction}

Cost sharing, which was introduced in Kenya in 1988, has led to an increase in school fees and a high dropout rate among learners at secondary school level. In 1988, the Presidential Working Party on Education emphasised the need for cost sharing in education between the government, parents and communities due to a decline in available government funds. The implementation of cost sharing in education, in context of rising poverty in the country, has led to adverse effects with regard to retention rates, access to and quality of education (Martin, 2008).

The implementation of the cost-sharing policy officially marked the end of "free" and highly subsidised education by government. However, the government would still be responsible for the remuneration of teachers and education administrators and fund some limited school facilities. It was not clear, even to the policy-makers, how the increasing demand for the limited number of secondary school places could be increased to enhance access to and participation in secondary school education and how the cost-sharing strategy in education would impact on this challenge (Orodho, 2002). Therefore, this article attempts to investigate the impact of the policy of cost sharing on education in selected Kenyan secondary schools in the Limuru district. More specifically the objectives of this article are:

1) to determine direct costs that parents incur as part of the cost-sharing policy to finance secondary school education; and

2) to assess the views of parents on the impact of the cost-sharing policy.

The study aims to provide information on the impact of the cost-sharing policy with regard to the allocation of education resources. It is hoped that the findings of this study would enlighten policy-planners on possible strategies to finance secondary school education in Kenya.

This research study is based on and guided by literature reviews and the classical liberal theory. The next section focuses on the literature review.

\section{Literature Review}

\subsection{Definition of cost sharing}

Cost sharing can be defined as an arrangement whereby the costs of the programme or project are shared by the 
involved parties, according to an agreed upon formula (Wambugu, 2012). Johnstone (2003) defines cost sharing in education as a shift in the burden of higher education costs; from being borne exclusively or predominantly by the government or tax payers to being shared with parents and students. Kiveu and Mayio (2009) have defined the costsharing policy as a situation where the government, on one hand, and households and communities, on the other hand, share the responsibility of financing education.

\subsection{The cost-sharing policy in Kenya}

A report by Reform Agenda for Education Sector in Kenya (2003) notes that cost sharing in education and other sectors has always been a feature of educational development in Kenya even before independence. This continued even in the post-independence period through the self-help movement (Harambee) system. Through this movement, the community has shared costs with government in the provision of a variety of basic human services and needs, including education. The decision to introduce cost sharing was occasioned by the shift in the national economic policy which, up until the change in policy, had seen visible government contribution in the financing of social services.

In Kenya, the financing of education is based on a cost-sharing policy introduced in 1988, which requires most costs in education to be met through partnerships between the public sector (government), non-governmental organisations (NGOs), religious organisations, development partners and communities (Government of Kenya, 1988). Within this funding policy framework, the overall government role includes financing professional development, teachers' remuneration in public institutions, the provision of infrastructure and administration, and management of bursary and scholarships for needy students. The responsibilities of other role-players include physical infrastructure development and maintenance, payment of fees for tuition, public examinations, catering and accommodation in boarding schools, students' personal expenses and remuneration of school/college non-teaching staff (Onsomu, Muthaka, Ngware, and Kosimbei, 2006).

Njeru and Orodho (2003) have also noted that, having accepted the rationality of cost sharing, the Ministry of Education, Science and Technology (MOEST) Bursary scheme was introduced as one of the safety measures to cushion the poor and the vulnerable groups against the adverse effects of cost sharing. The bursary scheme, however, remains inefficient and ineffective. Other characteristics that contribute to bottlenecks in the implementation of the bursary scheme at the secondary school education level include poor access and participation due to poor quality of service, bad governance and management weaknesses. It is, therefore, arguable that with more than half of Kenya's population living below the poverty line and the rising cost of education, the majority of households, especially among the poor and vulnerable groups, would not be able to invest in the development of quality education at the secondary school level (Njeru and Orodho, 2003).On average, households' contribution to the funding of secondary education amount to $60 \%$, while government's financing constitutes $40 \%$ of the aggregate. However, some schools which are categorised as "functional" charge far beyond $60 \%$ which becomes unaffordable especially to most poor parents. As a result, the financing of secondary education, that is, the cost-sharing strategy, has become problematic as parents have to shoulder an increasingly larger portion of the costs, thus, creating a negative impact on poor and vulnerable households (Njeru and Orodho, 2003). Ngware, Onsomu and Muthaka (2007) have made the same observation by indicating that the implementation of the cost-sharing policy was confronted with several problems. The authors argue that, there were no clear guidelines as to the extent to which parents and communities were expected to contribute as part of this cost-share programme.

Johnstone (2003) also made the observation that in recent years there have been a dramatic, albeit uneven and still contested, shift in the burden of education costs from a situation where the costs were predominantly borne by the government or taxpayers to this being shared with parents and students. Parents are now proportionately contributing more than government. This cost sharing, according to Johnstone (2003), took different forms, either through the introduction of tuition fees or, where it already existed, a sharp increase in the tuition fees, boarding, books and other costs associated with students' living expenses, which may formerly have been covered by the government (Marcucci, Johnstone, and Ngolovoi, 2008).

The following section focuses on the theoretical framework underpinning the study.

\subsection{Theoretical framework}

The study was based on the classical liberal theory. The classical liberal theory states that social mobility will be promoted through equal opportunity to education. The roots of this theory can be traced back to Rousseau (1712-1778) 
who claimed that in the "natural" state men were born equal and personal qualities should not jeopardise social equality so long as society rewards people according to their merits. Thus, the writers of the American Declaration of Independence claimed that all men are created equal in the sense that they are born with the same moral and political rights. It follows from this belief that social institutions such as education should, in some sense, attempt to treat people equally. The American educator, Horace Mann, (1796-1890) termed education the great equaliser. Evidence in favour of this belief is mainly in the form of case studies. There are numerous examples of people from poor families who have taken advantage of education opportunities and proceeded to obtain better jobs and higher incomes than they would otherwise have done. If the state did not provide education, free of charge, these individuals would have been denied the opportunity for advancement. There is a widespread belief that by removing economic barriers and making more places available in upper secondary and higher education institutions, and by increasing the length of attendance in the common school, the ideal situation could be created to implement the vision of equal opportunity, where everybody has access to the kind and amount of education suited to his/her inherited capacity. In the past, a great deal of weight has been attached to education as a tool to bring about greater equality and it has generally been assumed that increased spending in education will contribute to this end, as it will reduce dropout rates, repetition of a school year and absenteeism among the poor (OECD, 1975). In developing countries, where inequalities with regard to education provision are severe, it may be desirable, for the sake of equity and efficiency, to pursue the goal of equal distribution of educational opportunities. Inequality of participation means that the benefits of education are disproportionately enjoyed, with the children of comparatively wealthier families far more likely to complete secondary school or to enrol in higher education (Psacharopoulos and Woodhall, 1985), while poor families may not be able to afford to financially support their children through school, hence the propensity for higher dropout rates, absenteeism and repetition. These challenges also have an effect on the daily operations of public secondary schools.

In Kenya, the government has been subsidising education to enable more people to participate in education. However, with the introduction of the cost-sharing policy, and in the context of the existing poverty levels in the country and the rising cost of education, many parents may not be able to afford to enrol their children in a secondary school or to financially support their children through their secondary school education. Therefore, when taking into consideration equity, it is practically impossible to ignore the fact that unequal participation in education will, in the long run, worsen the status of the poor and vulnerable groups. The classical liberal theory, therefore, is relevant to this study as it was found that the cost-sharing policy discriminates against poor families who cannot afford to keep their children in school or to enrol their children at schools of their own choice.

\section{Research Method and Design}

Mouton (2001) defines a research design as a plan or blueprint of how one intends to conduct the research. This is further supported by Best and Kahn (2009), who define it as the plans and procedures for research that span the decisions from broad assumptions to detailed methods of data collection and analysis. A qualitative research design was used in order to establish the participants' perceptions, attitudes, understanding, knowledge, values, feelings and experiences about the phenomenon under study. What makes qualitative approach relevant for this particular study is that the researchers spent some time in the field (schools in this case) conducting interviews. However, the aim of the researcher was not to generalise the findings to all other similar schools in the Limuru district, but to provide objective information peculiar to these schools.

\subsection{The context of the study}

The study was carried out in Limuru district as previously indicated. The rationale for choosing the Limuru district was that the unemployment rate in this area is very high and there are high incidences of secondary school dropouts. In addition, there was the researcher' own interest and knowledge of the area. According to Singleton (1993), the ideal setting for the study is one that is directly related to the researcher's interest. He further points out that the setting should be easily accessible to the researcher and that it should allow immediate rapport with the participants.

\subsection{Sample and sampling procedure}

This research used purposeful sampling. MacMillan and Schumacher (2006) indicate that, to achieve authenticity in research reports, one has to focus on purposeful sampling as this reduces any chances of invalidity. In contrast to 
probabilities sampling, purposeful sampling select information rich cases for in-depth study. The researcher in this case purposefully targeted a group of people believed to be reliable for the study (Kombo and Tromp, 2006). The research was carried out on two schools (one a national, boarding school and the other was a district, day school) in the Limuru district. The participants were parents serving on the school district committee. This cohort of parents is believed to be knowledgeable about school operations.

\subsection{Data collection}

The main data collection tools were individual interviews. Qualitative in-depth interviews are noted more for their probes and pauses than their particular question format (McMillan and Schumacher, 2006). Topics were outlined in advance. Structured, as well as some open-ended, questions were asked. In a bid to enhance the validity of the data collected, interviews have been recorded on audiotape and the tapes were later transcribed. This process was sanctioned by the participants beforehand. Furthermore, piloting was done to help the researcher discover any weaknesses in the research design/instrument and to get any useful suggestions on how to improve the research question. The data collection for the pilot study was carried out in two other schools, which were not part of the final study.

\section{Findings and Discussions}

As stated earlier, the main objectives of this article were:

1. to determine direct costs that parents incur as part of the cost-sharing policy to finance secondary school education and

2. to assess the views of parents about the impact of the cost-sharing policy.

\subsection{Direct costs incurred by parents in education at secondary school level}

Data which related to direct costs incurred by parents were considered important for this study as it revealed the total costs that parents are supposed to pay as their share of the costs-sharing policy. Table 1 below shows the direct costs incurred by parents per year in secondary school education in the Lumuru district. Other requirements which have to be met by parents included: personal books such as dictionaries, an atlas, the Bible and a hymn book, exercise books; and personal items such as soap, pens, the school uniform and shoes.

Table 1: Fees charged in day and boarding schools in the Lumuru district

\begin{tabular}{|l|c|c|c|c|}
\hline \multicolumn{1}{|c|}{ Expense item } & $\begin{array}{c}\text { Day schools } \\
\text { Kenyan shillings (KShs) }\end{array}$ & $\begin{array}{c}\text { Boarding schools } \\
\text { Kenyan shillings (KShs) }\end{array}$ & Parent fee & Total \\
\hline & GoK Subsidy * & GoK Subsidy * & & \\
\hline Tuition & 3,600 & 3,600 & 0 & 3,600 \\
\hline Boarding, equipment and stores & 0 & 0 & 13,034 & 13,034 \\
\hline Repair, maintenance and improvement & 400 & 400 & 400 & 800 \\
\hline Local travel and transport & 400 & 400 & 500 & 900 \\
\hline Administrative costs & 500 & 500 & 350 & 850 \\
\hline Electricity water and conservancy & 500 & 500 & 1,500 & 2,000 \\
\hline Co-curricular activity & 600 & 600 & 0 & 600 \\
\hline Personal emoluments & 3,965 & 3,965 & 2,743 & 6,708 \\
\hline Medical & 300 & 300 & 100 & 400 \\
\hline Total school fees & 10,265 & $\mathbf{1 0 , 2 6 5}$ & 18,635 & $\mathbf{2 8 , 8 9 2}$ \\
\hline
\end{tabular}

* Government subsidy

The table above shows the proposed fee structures for day and boarding schools, respectively. The government pays a total of KSh 10,265 per student, regardless of their school category. Parents and guardians are expected to meet the balance, which can amount to KSh 18,635 . This is way above what most parents can afford. This high cost is prohibitive to, not only the poor, but also middle-class families.

Under the costs-sharing policy, parents are supposed to shoulder $60 \%$ of the total expenditure of secondary school education, while the government shoulder's 40\% (MOEST, 2001). It is important to note that this is not the fee charged in most schools. Some schools charge two to three times this amount. The government guidelines are largely 
ignored by a large number of head-teachers, boards of governors and parent-teachers associations, who, unilaterally decide to charge what they feel is realistic. With reduced government spending on schools, as part of the cost-sharing strategy in education, the current government policy on how schools should raise funds gives a lot of leeway to secondary school head-teachers to decide on the type of educational levies to impose on parents (Keveu and Mayio, 2009).

\subsection{Views of parents on the school fees charged}

The researcher gathered data on the views of parents about the school fees charged. These data were necessary to establish if the school fees charged, given the socio-economic context, was affordable or exorbitant. The majority of the parents interviewed indicated that the fees charged by schools are exorbitant. Most of them admitted that they could not afford it. One parent stated that "the school fee is too high for me to afford and they keeping on increasing the fees even in the middle of the year".

On average parents are spending a large proportion of their meagre income to pay for secondary education. Parents have to meet secondary school education expenses that are much higher than their income. More revealing was the fact that, because wealth in this district (Lumuru) is not equitably distributed, the majority of households have incomes that are below the expenses required to pay for the education of one secondary school student. Given that $56 \%$ of the Kenyan population is living below the poverty line, the great majority of household income per year is KSh 8,508 and the schools in the Lumuru district charge above KSh 10,000 per year per student in day and boarding schools, the inescapable conclusion would seem to be that children from poor households are denied secondary education because their parents cannot afford the associated expenses. Families with low incomes are unable to provide education to their children. UNICEF (1994) states that the costs associated with secondary school education are prohibitive, not only for the poor, but also to medium income households.

With regard to what the government could do to help to reduce the burden on parents, participants felt that the government should allocate more funds to the education sector. They suggest that this will enable schools to provide adequate learning facilities and will prevent the misuse of the policy as some schools may use the policy to ask exorbitant school fees which are not affordable, especially for students from poor and vulnerable communities. Participants also indicated that they would like to see the government subside the cost of education further by not only providing for professional development, teachers' remuneration and infrastructure development, but also offering free education for students who need financial assistance. One of the parents indicated: "The government should subsidize school fees as much as possible and provide schools with adequate facilities."

It was clear that the participants were of the view that the government was not doing enough, that it could undertake to improve the cost-sharing funding system to improve accessibility to secondary education for all the students, irrespective of their socio-economic background.

Asked how they raise money to educate their children, some parents said that they use their family resources to ensure that their children remain in school. Most of those who earn a salary often have to take bank and cooperative loans to pay for their children's education. Others indicated that they have to hold more than one job to raise enough money to educate their children. They, therefore, also felt that the government could approach more NGOs and government agencies and persuade them to partner with government to ensure that all Kenyan students have access to secondary education since. As was noted by Education for All (2001), secondary education is part of basic education in Kenya and failure to provide basic education seriously compromises a country's effort in reducing poverty.

\section{Conclusion}

From the findings of this study, the following conclusions were made: parents viewed cost-sharing as a burden; the costs of education were too high, especially for the poor parents and they called for a reduction of education costs. The study also found that there are still more measures that could be adopted to improve the policy in order to make education more accessible.

\section{Policy Recommendations}

Based on the findings of this study, the researcher makes the following recommendations:

i. The government should sensitise the public on the need of the cost-sharing policy so as to bring many role- 
players aboard.

ii. The government should establish the unit cost of secondary education and come up with fee guidelines that are acceptable to all and put in place policies to ensure that school administrators adhere to these fee guidelines.

iii. The government should introduce effective policies to identify the bright and poor students so that they are not left out of secondary education due to their inability to afford the school fees.

iv. The government should also come up with effective policies to identify committed school managers (Board of Governors) to assist in the administration of the bursary fund in order to reach the poor who are supposed to be the only beneficiaries.

v. There is a need for schools to start income generating projects and both parents and students should be encouraged to participate in these projects in order to subsidise the cost of education.

vi. Schools should follow-up on students who stay out of school for more than one week and assist these students by helping them to catch up with the schoolwork they have missed while they were at home. This could contribute to students, from poor and vulnerable families, feeling less marginalised, because of their socio-economic circumstances.

vii. There is a need for the introduction of a better method to finance education which would enable the poor to enrol at schools of their choice.

\section{Limitation of the Study}

As this research was done in only two secondary schools in the Limuru district, the results cannot be generalised. There is, therefore, a need to carry out further research in more learning institutions on the topic, to determine the influence and impact on this policy in the whole country as this would go a long way in assisting the policy-makers adopt measures that will enable all students in secondary schools access the much desired education that would make them better scholars and citizens.

\section{References}

Best, W.J., \& Kahn, V.J. (2009). Research in education. New Delhi: Pearl offset press.

Johnstone, D.B. (2003). Cost-sharing in higher education: tuition, finance assistance and accessibility. Sociological Review, 39(3), $351-374$.

Kiveu, N., \& Maiyo, J. (2009). The impact of cost-sharing on internal efficiency of public secondary schools in Ndivisi division of Bungoma district Kenya. Educational Research and Review, 4(5), 272-284.

Kombo, D., \& Tromp, T. (2006). Proposal and thesis writing: an introduction. Kenya: Paulines Publications Africa.

Macmillan, H., \& Schumacher, S. (2006). Research in education: evidence-based inquiry. 6th Edition. Boston: Pearson Education Inc.

Marcucci, P., Johnson, B., \& Ngolovoi, M. (2008). Higher educational cost-sharing, dual-track tuition fees and higher education access: the East African experience.

Martin, E. (2008). Inequalities in education: poor still marginalised. Daily Nation, 8 May, 14:5.

Mouton, J. (2001). How to succeed in your master's and doctoral studies: a South African guide and resource book. Pretoria: Van Schaik.

Ngware, N.N., Onsomu, E.N., \& Muthaka, D.I. (2007). Financing secondary education in Kenya: Cost reduction and financing options. Education Policy Analysis Archives, 15(24).

Njeru, E., \& Orodho, J. (2003). Education financing in Kenya: secondary school - bursary scheme implementation and challenges. Institute of Policy Analysis and Research Discussion Paper (IPAR DP/035/2003), Nairobi.

OECD. (1975). Education Equality and Life.Vol.1 Paris. OECD.

Onsomu, E.N., Muthaka, D., Ngware, M., \& Kosimbe,i G. (2006). Financing of secondary education in Kenya: costs and options. Nairobi: Kenya Institute for Public Policy Research and Analysis (KIPPRA).

Orodho, J.A. (2002). Enhancing access and participation in secondary education among the poor and vulnerable through bursaries in Kenya. A consultancy paper submitted to the Institute of Policy Analysis and Research (IPAR) for Publication.

Psacharopoulos, G., \& Woodhall, M. (1985). Education for development: an analysis of investment choices, Washington D C: Oxford.

Republic of Kenya, Ministry of Education, Science and Technology. (2001). Education for all: a national handbook for 2000 and beyond. Nairobi: Government Printer.

Republic of Kenya. (1988). Report of the Presidential Working Party of Education and Manpower Training for the next decade and beyond. Nairobi: Government Printer.

Rousseau, J.J. (1712-1778). Emile for Todat. The Emile of Jean Jacques Rousseau, Selected and Interpreted by William Boyd. London: Heinemann.

Singleton, R.A. (1993). Approaches to social research. New York: Oxford.

UNICEF. (1994). Comprehensive education sector analysis report. Nairobi. UNICEF Country Office.

Wambugu JW (2012) The impact of the policy of cost sharing: A case study of selected Kenyan secondary schools. Unpublished Masters Dissertation. University of South Africa. 